\title{
群馬大学附属図書館におけるLAN接続CD-ROM検索システム （LASSIE）の開発
}

\author{
Development of a LAN-Associated CD-ROM Searching System \\ (LASSIE) in Gunma University Library
}

\begin{abstract}
若林 克己* 川島 一 ${ }^{*}$ 橋本登美雄 ${ }^{*}$ 北村 武夫* 三森 健吉* 関 篤 ${ }^{*}$ 群馬大学附属図書館
\end{abstract}

\begin{abstract}
Wakabayashi K., Kawashima H., Hashimoto T., Kitamura T., Mitsumori K., and Seki A. : Development of a LAN-Associated CD-ROM Searching System (LASSIE) in Gunma University Library. Igaku Toshokan $1991 ; 38(3): 260-269$.

A local area network (LAN) was constructed at the Showa Campus of Gunma University where the School of Medicine, University Hospital, Institute of Endocrinology, and College of Medical Technology are located. A CD-ROM server (CD-server, Meridian Data, Inc., Scotts Vally, CA, USA) was connected to the network with a Sony Quarter $L$ as a network file server for multi-users on campus. As the majority of users had NEC personal computers, the software for the operation of the CD-server was developed to work with NEC as well as IBM equipment. After coordination of the software for the CD-server, SilverPlatter CD-ROM, and netware server in cooperation with MARUZEN, USACO Còrp., and TOYOCOM, we finally succeeded in developing a system which we termed LASSIE (LAN-Associated Service System for Informational Exploration). This system, which can include NEC personal computers, is the first trial in the world, and is to be expanded to cover 3 campuses of the University, and also to cover more databases within a year. Trials to simplify the software, procedure, and equipment, and how funding was procured are also described.
\end{abstract}

\section{I .はじめに}

図書館サービスの中で情報検索の占める割合は 年々増大し, 利用者の要求にどう対応するかが重 要な問題となって来ている。わが国では学術情報 センターや日本科学技術情報センターあるいは

\footnotetext{
* Katsumi WAKABAYASHI, Hajime KAWASHIMA, Tomio HASHIMOTO, Takeo KITAMURA, Kenkichi MITSUMORI, and Atsushi SEKI : Gunma University Library. 4-2, Aramaki-machi, Maebashi 371, Japan.
}

（1991年 7 月 4 日 受理）
DIALOGのオンライン情報検索等の利用が一般 的であるが, 検索費用の面で研究者にとっては, かなりの負担となっている。最近いくつかのデー タベースがCD-ROM化され，利用に供されてお り, 群馬大学では昭和 63 年度の予算で購入し, 平 成元年 4 月から供用を開始した。しかしスタンド アロンのパソコンによる検索は，年代ごとにCD を交換しなければならないことに伴う手間とCD 損傷の危険性, 順番待ち, 特に医学部では開館時 間中に図書館に来ることの困難等使用上いくつか の問題が生じ, 利用者側から改善の要望が出るよ うになった。一方市場にはCD交換の手間を不要 
にするCDチェンジャーやCDサーバーも現われ， 先行大学では図書館内に敷設したTHIN-ETHER にCDサーバーを取り付けて数台のパソコンで同 時に検索を可能にする試みが行われ，平成 2 年度 の全国国立大学図書館協議会総会の研究集会に大 阪大学, 東京工業大学の附属図書館から発表され た。我々群馬大学では, キャンパスLANにCDサー バーを接続させることによって, キャンパス内の 研究室からCD-ROMの利用を可能にすることを 計画し, 平成 3 年 5 月に完成し, 実験期間を終え, 6 月より一般への共用を開始することになった。 このシステムを我々はLASSIE(LAN-Associated Service System for Informational Exploration) と言う愛称で呼ぶことにした。

このようなシステムに関してはハード，及びソ フト面のノウハウは勿論であるが, システム構築 のための費用が, 群馬大学ではどのような予算的 サポートによって可能となったかと言う事実もま た重要な情報と言えよう。本稿ではLASSIEの完 成に至る経緯の詳細と, 群馬大学の固有の, しか しこのようなプロジェクトに対して極めて効果的 な予算措置について報告したいと思う。

\section{CD-ROM導入からLASSIEまで}

昭和63年 9 月, 本学の部局長会議の席上, 前川 正学長から教育研究学内特別経費が本年も使用可 能になったと言う報告と，その使用方針が説明さ れた。即ち，1）細分化はしない，2）学部間の 持回りはしない，3）いくつかの学部にまたがっ た，または大学全体に関するプロジェクトである こと，4）将来に形として残るようなものである こと，5）科学研究費や概算要求で要求できるも のではないこと，と言うことであった。

教育研究学内特別経費は国立大学全てに与えら れるあのであり, その使途に学長の裁量を強く影 響させることのできるこの予算は，とかくこれま
で国立大学運営上の欠点と言われた「貧乏な学長」 をいくらかでも解消すると共に, 学長の力量の試 される予算であある。上記のような本学学長の方 針は, 数ある国立大学の中であ極めて特色のある あので，大学全体のレベルアップにつながるプロ ジェクトに対して重点的資金投入を可能にするす のであった。

当時, 新任の附属図書館長として部局長会議に 出席していた筆者の一人若林は, 附属図書館の全 学的性格から図書館のサービス機能の充実とこの 予算との結び付けに思い至り，その場で前川学長 に図書館からの要求も可能であるか否かを質問し, あちろん結構であるとの返事を得た。この時脳裏 には登場したばかりのニューメディア, CD-ROM がターゲットとして浮かんでいた。図書館では早 速CD-ROM読み取り装置としてのパソコンとCDROMドライブ，ハードディスク（HD），そして 購入すべきデータベースを調查し, 大学図書館と してニューメディアに対応することの重要性を論 じた要求書を提出した。

前川学長は,この年の教育研究学内特別経費を 二分して，本部のある荒牧キャンパスでのLAN の設置と，図書館でのCD-ROM導入に使用する ことを決定された。思えばこの二つの用途は，後 のLASSIEの誕生を暗示しているのである。

群馬大学には三つのキャンパスがあり, 三つの 図書館がある。このような施設の導入については 3 館を公平に扱わなければならない。CD-ROM の製品にはIBM対応の外国製品と，NEC等に対 応する日本製品とがあり，結局ハードとしては各 館にIBMコンパチブルのSANYO-AXパソコンと $\mathrm{CD}$-ドライブ，そしてNEC用のCDードライブを 設置し，ソフトは各キャンパスの希望に沿うよう 決定した。特にMEDLINEのような継続物は, 二 年目以降の継続のための予算をキャンパスでサポー トできることを確認してから決定した。このため, この費用で購入できた大型のデータベースは1985 
年からのDIALOG ON DISKのMEDLINEと朝日 新聞データベースに留まった。昭和キャンパスで のMEDLINEの提供は非常な反響を呼び, 順番待 ちに不満が出, 翌年から医学部の費用でパソコン 1 台を追加，また SilverPlatter の MEDLINE が 1966年以降をカバーし，費用の点からも有利であ るため翌年度から切り替えられた。

CD-ROMの導入は好評を持って迎えられた， 特に医学部のある昭和キャンパスにおいては 2 台 のパソコンは殆ど常時使用され, 午後の時間帯で は順番待ちを必要とした。他のキャンパスでは教 官の協力を得, 授業にCD-ROM検索によるレポー トの作成などを取り入れて戴いた。その後荒牧キャ ンパスの本館では, 教育学データベースERIC, 心理学データベースPsycLITが関係教官達の研究 費拠出で導入された。図書館報であ毎号キャンペー ン記事を掲載して，周知に努めた。

このような努力と成果は学長の認めるところと なり, 次の年度における教育研究学内特別経費の 一部を図書館のAV機器およびソフトの充実に関 して使用することが認められた。残りの部分は工 学部のある桐生キャンパスにLANを敷設するこ とに用いられた。これらのLAN敷設はLASSIEの 将来の発展に対する重要な布石となった。

平成 2 年度の全国国立大学図書館協議会総会に 出席した我々は，前述のような東京工業大学, 大 阪大学のCDサーバーに関する発表を聞き，その 上を行く構想としてLANとCDサーバーとの接続 を次の目標に定めた。それまでLANの有用性に やや疑いを持っていたが，CDサーバーという目 玉を得, 昭和キャンパスにおけるLANの敷設と 連携させて, 教育研究学内特別経費に対する図書 館のプロジェクトの策定に取り掛かった。幸い若 林は当時昭和キャンパスの情報処理センター分室 長を兼任していたので，昭和キャンパスにおける LAN敷設の要求をキャンパスにある医学部, 内 分泌研究所, および医療技術短期大学部全体の要
求として提出することを各部局に認めて戴き, 図 書館側としてはLANに接続すべきCDサーバーと, 同年文部省から工学部分館に設置することを認め られたG 4 ファクシミリと平行して荒牧, 昭和の キャンパスにあISDNタイプのG 4 ファクシミリ を設置して高速ファクシミリネットワークを作る, と言うプロジェクトを組み合わせた図書館情報シ ステム構築という予算要求を提出した。この両者 が学長から認められたことによって，LASSIEが 誕生することになったのである。

\section{LASSIEの構成と問題点およびその解決}

昭和キャンパスにおけるLANは図 1 に示すよ うに, 図書館の存在する医学部臨床研究棟 $\mathrm{A}$ と周 辺の 3 棟はETHERNETケーブルでつなぎ，やや 遠距離の医療技術短期大学部之附属病院病棟 は, 間に光ケーブルを用いた。同時にLAN敷設 とLASSIEの計画をキャンパス内の各講座, 研究 室に通知し，LANとの接続口となるウォールジャ ックの取り付けの希望の有無と位置を調查した結 果, 図書館を除き, 医学部 47 , 附属病院 3 , 内分 泌研究所 11 , 医療技術短期大学部 21 , 合計 82 䇢所 の設置の要求が出された。

これらLAN関係の工事が進行しているうちに, 平成 3 年 3 月に Meridian Data Inc.のCD サー バーが医学部分館に到着した。このCDサーバー にSONYの Quarter L PCX-300をネットワーク・ ファイルサーバー（ネットウェアサーバー）とし て接続し，それまでスタンドアロンで使用してい た 2 台のIBMコンパチブルの, SANYO AXパソ コンMBC-17JH40をTHIN-ETHERで接続して, サービスを中断することなく新しい形式に移行さ せた。この段階では他の大学のシステムと変わら ない。LANへの接続に当たってはLANに異常が 発生した場合にも図書館内のネットワークを運用 できるように考えてはどうかという東洋通信機の 


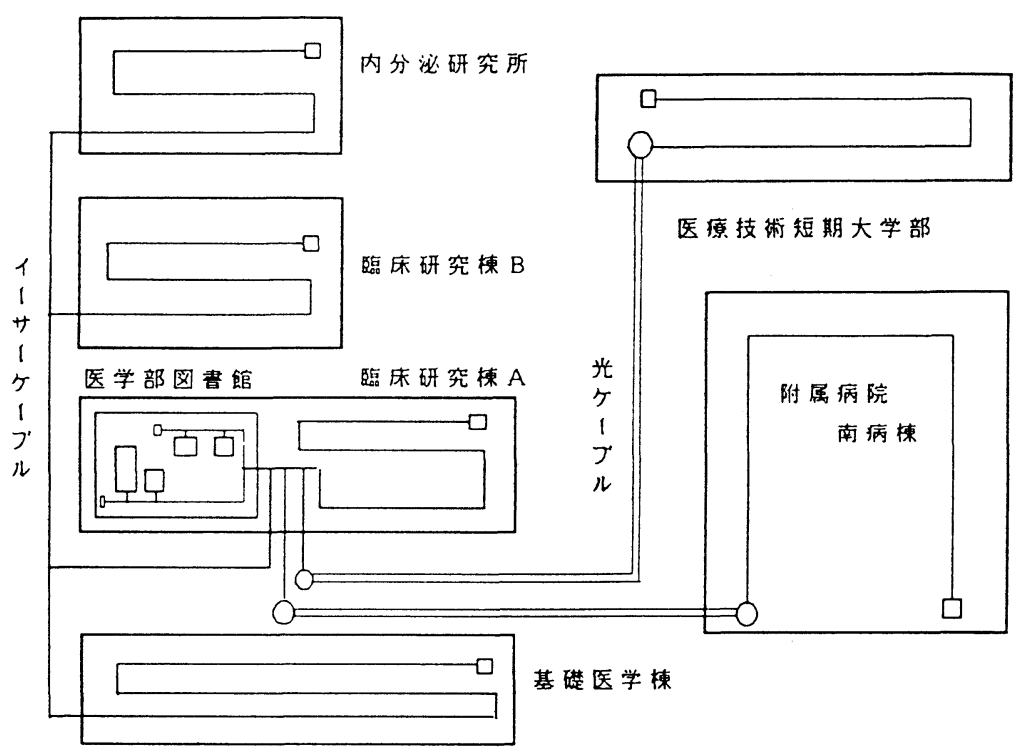

図1．昭和町キャンパスLANの構成

アドバイスああって, 図 2 のようにデータリンク ブリッジをネットサーバーと図書館内のパソコン の間に挿入し，それをLANのウォールジャック を介してキャンパスLANに接続するという形を 採った。

CDサーバーをLANに接続して利用することで の最大の問題は，このシステムが，むともとは IBMマシンを対象にしてできているということで ある。これまでのように図書館の一室に限られて いるような小規模なネットワークでは, IBMまた はそのコンパチブルマシンを購入すれば全く問題 ないのであるが，我々の計画のようにキャンパス 全体の研究室にその範囲を広げると, 研究室にあ るパソコンは圧倒的にNECないしはそのコンパ チブルマシンであり, それらの器械が使用できな ければ意味が無い。我々は, CDサーバーを扱っ ている丸善, CD-ROMを扱っているユサコ, LAN の専門業者である東洋通信機の三者を集め, NECにも通用するシステムへの改善を要請した。 幸い, SilverPlatter の CD-ROM 検索ソフト
SPIRSは, NEC用のバージョンができ上がったば かりで, 東京工業大学からの情報では一応使用に 耐えることが認められていたし，東洋通信機の LAN通信用のPCボードもNEC対応の製品のある ことがわかったが，CDサーバー側のソフトには IBM対応のものしかなく, 実際に試してみると, NECでは14台あるうちのひとつのCDドライブに しかアクセスできないことが判明した。この点を 丸善に指摘し, 丸善からMeridian Data社に NECのパソコンにあ対応するCDサーバーコント ロールプログラムの作製を依頼するよう要請した。 このプロクラムのバージョンアップは平成 3 年 4 月に完成し，業者間の共同テストでオペレートす ることが確認された。

平成 3 年 5 月初旬にLANの敷設は完了し, 若 林の研究室に引き込まれたウォールジャックと使 用しているNECコンパチブルのパソコン, EPSON PC-386VRとを接続して実地テストが行われた。 このパソコンには, 2MBのEMSとハードディス ク（HD）が装備されており, 東洋通信機のNEC 


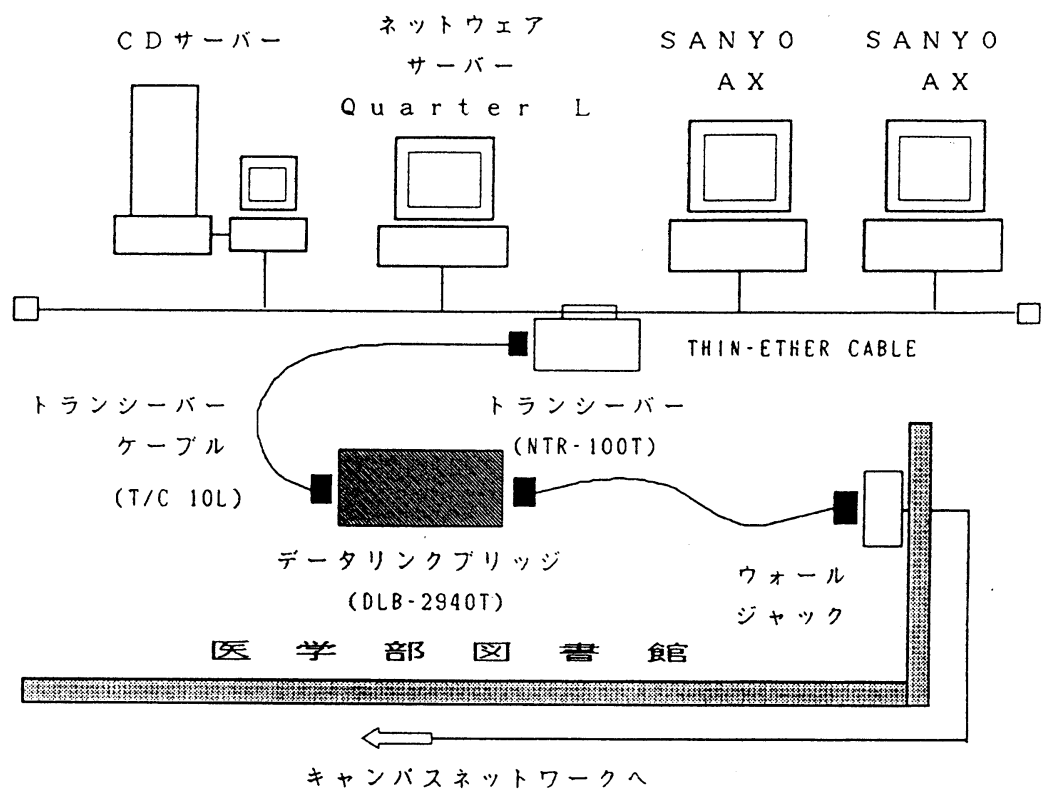

図 2 . 図書館医学部分館内のネットワーク構成

対応PCボードCentreCOM SIC-98をスロットに 装着し，まず東洋通信機の技術者がTCP/IP と NetWareの双方をサポートするようにソフトウェ アをフロッピーディスク（FD）にインストール した。更に丸善の技術者により，CDサーバーの コントロールプログラムと, ユサコの検索用ソフ トSPIRSをHDにインストールしてから装置を立 ち上げ, 図書館内のCDサーバーにセットされて いるMEDLINEの検索を試み, すべてのプログラ ムが正常に㗢くことが実証された。

\section{IV. 必要亡されたハードウェア, ソフト ウェアと費用}

スタンドアロンでの検索に必要であったパソコ ンはSANYO AX MBC-17JH40がそうであるよ うに，1 MB程度の内部メモリーとHD（これは 最小のサイズで良いが）が必要であった。そのた めLANに接続する場合にもNECマシンでは内部 メモリーが640KBであるため, EMSとHDDの双
方を装備したものでテストした訳である。

一方このシステムで必要なソフトは, 前述のよ うに, CD-ROM検索ソフト（ユサコ）, CDサー バーコントロールソフト (丸善), 及びLAN接続 用ソフト (Allied Telesis 社製, 東洋通信機扱 い）であるが, 検索ソフトは無料で貸与される ことになった。ファイルサーバー運用ソフトであ るNovell 社 のAdvanced NetWare とMeridian Data社のCDサーバーソフトはCDサーバー購入 予算に含まれている。

従って, LAN敷設開始の時点で計算された LAN接続のための研究室負担額は次のとおりで ある。この際ウォールジャックからパソコンまで のトランシーバケーブル $5 \mathrm{~m}$ は共通費用でまかな われる。

1.PCボード（NEC対応PC-SIC N980T）： $¥ 99,800$ （IBM対応ボードは $¥ 109,800 ）$

2. CentreNET PC/TCP ソフトとインストー ル料金 : $¥ 22,500$

3. EMS $¥ 20,000 \sim 30,000$ 
4. HD $¥ 100,000$

その後平成 3 年 4 月の時点では, PCボードは $¥ 49,800$ （IBM $¥ 59,800 ）$ と值下げが行われたが, やはり全てを備えるとすれば，かなりの負担額と なる。LAN加入者にすべてこのような条件を要 求することが妥当であろうかという疑問を我々は 抱いた。できるだけ多数の研究者, 学生にCDROM検索を利用して貪うには，できる限り単純 な（すなわち安価な）設備条件が必要である。あ まり多額な費用を要求したのではせっかくIBMオ ンリーからNEC対応にした意味がなくなってし まう。

そこでシステムの単純化を試み, 最低の費用で 検索を可能にするにはどうするかを検討すること にした。

\section{V. 構成の単純化 : ソフトゥェアの整形に よるハードウェアの省略と自動化}

LANの機能をすべてカバーするソフトとは別 に, 研究室からのCD-ROM検索のみを可能にす る最も単純なシステム構成を考えてみた。この単 純なシステムは研究費などの点で，できるだけ安 価に検索をしたいという利用者や, 複雑なネット ワーク操作の手順は苦手というビギナーに対して 役立つあのである。

まず, 前述の 3 業者によって若林の研究室にイ ンストールされた, ソフトシステムを動かしてみ ると,

1. FDから立ち上げる。

2.LANに載せるプログラムが作動して, 図 書館のCDサーバーに付いているファイルサー バーに接続する。

3. HDへ移行する。

4.ファイルサーバーの仮想ドライブに切り替 える。

5.ここでログインする。
6. 検索のためのSETUPバッチプログラムを 起動させ, 諸条件をサーバーにセットする。

7. ドライブをHDに戻し, SilverPlatter の検 索プログラムSPIRS.EXEを始動し，検索を 始める。

8. 終了したらファイルサーバーのドライブに 切り替え, ログアウトする。

と言う順序を踏み, ステップ 3 以後は手動で行 わなければならないことがわかった。

業者が違うために連携のとれていない一つの例 として，ログインしなくてあ検索ができるし，こ の際ログアウトの必要もない, という事実がある。 これは管理上具合いが悪いし，同時に 2 人以上が 行った場合トラブルが生じる可能性があるという。

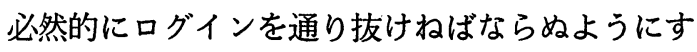
るため，筆者の 1 人，川島は SPIRS.EXE 関係 のプログラムをファイルサーバーに移動させても 検索が可能かどうかを検討した結果，2台のパソ コンから同時にアクセスしても移動させた SPIRS は作動することが確かめられた。このことはHD に格納されていたSPIRS.EXEの部分が不要とな ることを意味し，HD省略の可能性が生まれた。 勿論NEC用のSPIRSはIBM用のSPIRSとは別のディ レクトリNECSPIRSに収納されている。また, ファ イルサーバーに接続したあとNECSPIRSのディレ クトリに入り込んで, SPIRSを起動し, 終了した ら自動的にログアウトするバッチプログラムNEC SPIRSを作製し，ファイルサーバーに格納した。 ネットウェアのシステムでは, 管理者からのメッ セージを利用者に伝えることができるので，ログ インの後でメッセージをディスプレイに表示させ るようにセットした。

さて，上記の作動をするように作られたFDの 方の内容を見ると，

ルートディレクトリ：MS-DOSのシステムと CONFIG.SYS, AUTOEXEC.BAT

ディレクトリPCTCPには41個のファイル, ディ 


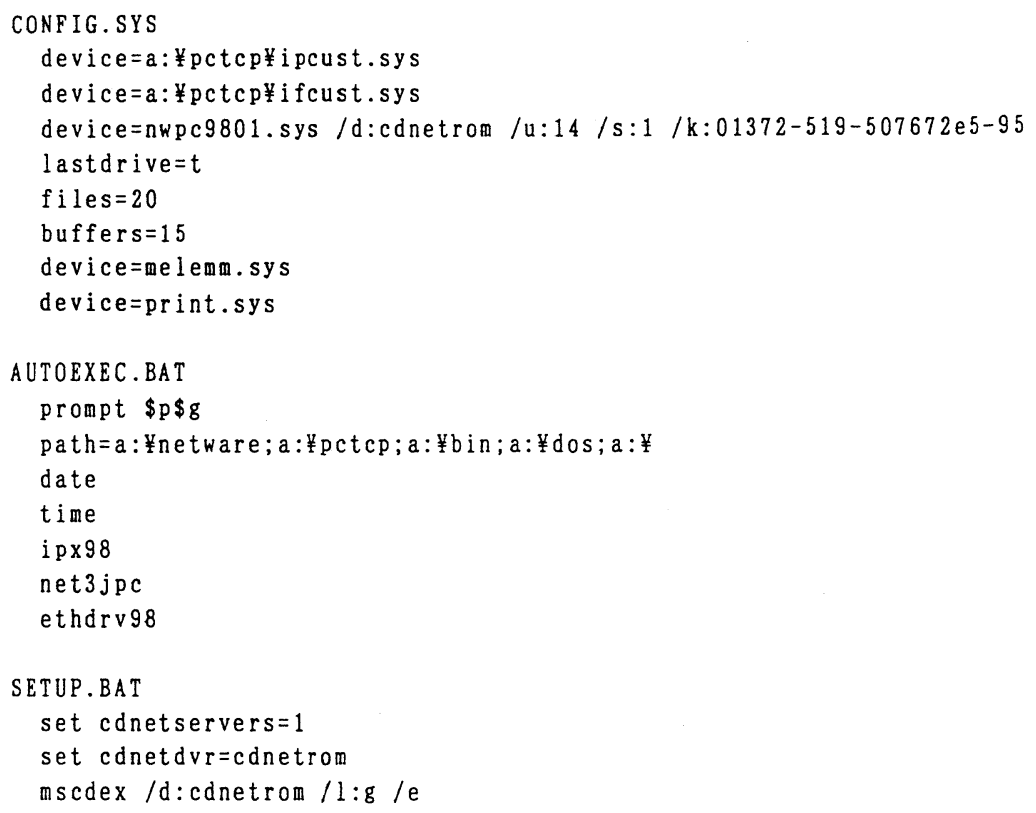

図 3. 最初のCONFIG.SYS, AUTOEXEC.BAT, SETUP.BAT

レクトリNETWAREには, CFGIPX.EXE, NET 3JPC.COM, IPX98.COM の 3 個, そのサブディ レクトリPUBLICには, COLORJPC.EXEとJPC \$RUN.OVLの 2 個のファイルが入っていた。

CD-ROMの検索にはTCP/IPに関する部分は必 要ないはずである。CONFIG.SYSとAUTOEXEC. BATプロクラムの内容を哯いてみると, 図 3 の ようになっていた。

念のために東洋通信機のプログラムを自分でイ ンストールプログラムに従ってインストールした あのとくらべ，TCP/IPの部分を省略するように 書き直した。即ち，FDからディレクトリPCTCP を削除し，CONFIG.SYSでのDEVICE指定を削 除した。更に NETWARE のサブディレクトリ PUBLICを削除し，一方HDに存在するSPIRSプ ログラムを取り除き，SETUP.BATとそこに指定 されているプログラム MSCDEX.EXE 及び CONFIG.SYSに指定されているNWPC9801.SYS, NWDRIVER.SYSをFDに移動させると，全てが FDに納まり, HDは事実上必要なくなってしまっ
た。ドライブの数や番号を整理して, 最終的には 図 4 に示すようなプログラムを作製した。この際, FDのファイル構成は図 5 のようになった。

このFDをセットして立ち上げると，CONFIG. SYS, AUTOEXEC.BATの順に実行されて行く ログインむ自動的に行われる。使用者はサーバー からのメッセージを見た後でどれかキーを押すだ けでよく，ビギナーであ問題なく使用できる。 SPIRSの使用法即ち検索の方法さえわかっていれ ばよく，これまで図書館で利用しているとおりで ある。

次の問題は内部メモリーの拡張である。LAN 接続のためのプログラムの常駐のためによ゙うして あ300KB程が使用され，SPIRSのプログラムを動 かすためには更に512KB以上が必要なので， 640 KBの内部メモリーを持つ機種では不足になり, 1 MB以上のEMSを装着することが必要であるとい う結論になった。

上記のような手直しにより, 最小限内部メモリー の拡張のためにEMSを備えるだけでLASSIEの利 
CONFIG.SYS

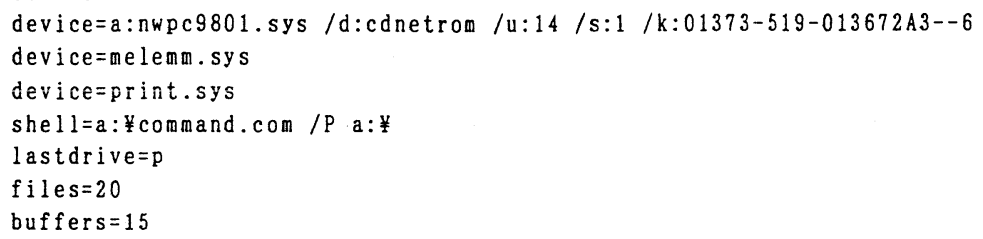

䝬 / $\mathrm{u}: 14$ はCDサーバーのドライフ数、/s:1 はCDサーパの数、/K：以下にある数 列はアクセスするためのキーナンバーである。これについては後に述べる。LASTDRIV $\mathrm{E}=\mathrm{P}$ はドライフCからCDサーパーが始まるため最後が $\mathrm{P}$ なる。

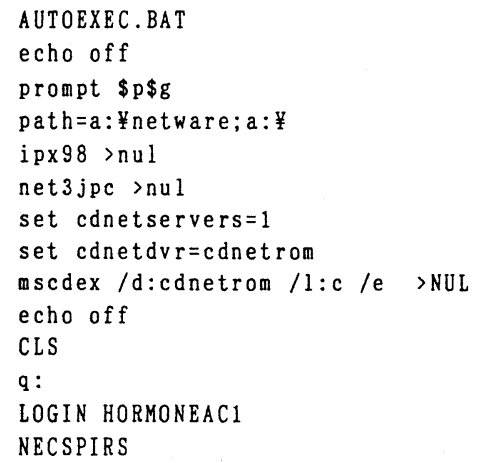

註このAUTOEXEC.BATは最初のAUTOEXEC.BATとSETUP:BATをひとつにしたものであ る。 / : c はCDサーバーの最初のドライフ番号がCであることを示す。/eは内部义 モリーを拡張して使用することを示している。q：はファイルサーバーの仮想ドライ ブ番号である。ここでユーザー名とともにログインする。ここでファイルサーハーか らのメッセージかあれは、画面に表示される。メッセージを䛨んた後キーを吅くとサ ーバーに格納されているパッチブログラムNECSPIRSか起動され、サフティレクトリに 入り込んでspirsを実行する。終了すると自動的にログアウトして最初のドライフに 䒝る。

図 4.最終的なCONFIG.SYSとAUTOEXEC.BAT

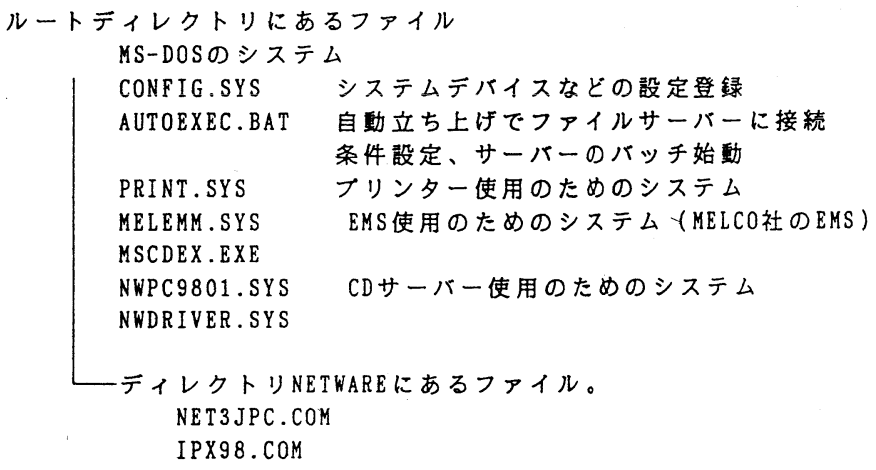

註 このファイル構成はパソコン側のFDのものである。SilverPlatter MEDLINE検 索のためのソフトspirsその他は、ネットウェアサーバーに入っているので、それを 使用する。

図 5.CD-ROM検索のみ行うときのファイル構成 
用ができることになった。

しかし，色々試みているうちに，面白い事実が 判明した。その事実とは, 内部メモリー640KBの マシンでも，HDを装備していると，EMSを使用 しなくてもSPIRSのプログラムが動くということ である。言い替えれば, パソコン側としては, EMS かHDのいずれか一方を備えていれば，SPIRSを 使って検索ができるのである。しかしながら， TCP/IPにも対応できるようにインストールした FDを使用してみると，より多くの内部メモリー を使用してしまうため，HDによるカバーは効か なくなり，EMSあ必要となることも判明した。

\section{VI. 供用の開始まで}

研究室からの試行の成功によって, 供用の具体 的な手順に取り掛かった。平成 3 年 6 月 7 日に, 説明会を開いた。この説明会の形式は, 全申し込 み者に周知徹底が必要なため, 全員を一時に集め ることをせず，2 時間の間に会場に来れば良いこ とにして，その間に出席をチェックしながら 5 回 の説明とデモンストレーションをし，同時に説明 書と, 登録ユーザー名, パソコンの機種と装備の 状態, TCP/IPソフトの希望の有無を記入するよ うになっている申込書を手渡した。結局不参加者 は6名にとどまった。この申込書を医学部用度係 で取りまとめ，PCボードとTCP/IPソフトの一括 購入を行った。最初のウォールジャックの申し込 みからPCボードの申し込みに至る部局別の内訳 は表 1 に示すとおりであった。この中には図書館 分館の分 3 台は含まれていない。ウォールジャッ クの取り付けを申し込んだ82箇所のうち66箇所が 即座に機能開始を望んでおり，そのうち56箇所は 現在費用が多少掛かっても検索のみでなく，完全 なLANの機能を装備したいと望んでいることが わかった。検索だけできればよいという利用者は 10箇所であった。一方パソコン機種に関しては,
表 1. LAN加入申込内訳

\begin{tabular}{|c|c|c|c|c|c|c|}
\hline & $\begin{array}{l}\text { ウォールジャック } \\
\text { 取付け申込 }\end{array}$ & $\begin{array}{l}\mathrm{PC} \\
\mathrm{TCF}\end{array}$ & $\begin{array}{l}\text { ボー } \\
\text { /IP } \\
\text { 要 }\end{array}$ & $\begin{array}{l}\text { ச込 } \\
\text { フフト } \\
\text { 不要 }\end{array}$ & 豆計 & 合計 \\
\hline 医 学 部 & 47 & $\begin{array}{l}\text { IBM } \\
\text { NEC }\end{array}$ & $\begin{array}{r}1 \\
26\end{array}$ & $\begin{array}{l}0 \\
6\end{array}$ & $\begin{array}{c}1 \\
32\end{array}$ & 33 \\
\hline 附属病院 & 3 & $\begin{array}{l}\text { IBM } \\
\text { NEC }\end{array}$ & $\begin{array}{l}0 \\
2\end{array}$ & $\begin{array}{l}0 \\
0\end{array}$ & $\begin{array}{l}0 \\
2\end{array}$ & 2 \\
\hline 内分泌研 & 11 & $\begin{array}{l}\text { IBM } \\
\text { NEC }\end{array}$ & $\begin{array}{l}1 \\
7\end{array}$ & $\begin{array}{l}0 \\
2\end{array}$ & $\begin{array}{l}1 \\
9\end{array}$ & 10 \\
\hline 医療短大 & 21 & $\begin{array}{l}\text { IBM } \\
\text { NEC }\end{array}$ & $\begin{array}{r}1 \\
18\end{array}$ & $\begin{array}{l}0 \\
2\end{array}$ & $\begin{array}{r}1 \\
20\end{array}$ & 21 \\
\hline 合 計 & 82 & & 56 & 10 & 66 & 66 \\
\hline
\end{tabular}

IBMまたはそのコンパチブル機種は僅か 3 台に過 ぎないことが判明し，NEC対応を積極的に推進 したことが的を得ていたことになる。心配した内 部メモリ一の拡張やHDも，既に装備されていた り，この際装備するという利用者が非常に多いこ とは, LASSIEに掛ける期待の大きいことを示す ものであろう。

LAN加入とTCP/IPソフトの組み込みを促進す ることになった大きな要因は，費用の点であろう。 前述のように必要な費用の概算は, 平成 2 年の秋 に行われた試算と比べると，50,000円安となった ことは，朗報であった。

現在CDサーバーは既に稼働しているため，PC ボードの装着がなされ次第利用が開始される。

我々の作製した簡便, 自動ソフトは, TCP/IP ソフトの組み込みいかんに関わらず使用できるす のである。そこで, 各利用者の持参するMSDOS のシステムの入っているFDにプログラムをコピー し，ユーザー名を書き込めば，CDサーバー検索 専用のFDができ上がり，即使用できることにな る。 


\section{VII. 最後の問題}

IBMとNECのパソコンをカバーするLASSIEの プロジェクトはわが国, いや世界でも最初の試み であるため, プロジェクトが進むに連れてさまざ まな問題が生じてきた。特に Meridian Data 社のCDサーバー用のNEC対応ソフトはまだプロ トタイプと言ってあ良いし，ユサコのNEC対応 検索ソフトSPIRSにも問題があり, 近く新バージョ ンがでるとのことである。ソフトを提供している 日本の代理店, 丸善やユサコの方々がNEC対応 ソフトに今後充分に精通されるよう期待する。

さて, 我々が最後に突き当たった問題はCDサー パーのソフトである。

我々に丸善から最初に提供されたNEC対応の Meridian Data 社のソフト（バージョン4.0）で は, 各ューザーにキーナンバーを割り当て, CD サーバーにアクセスするには，キーナンバーを CONFIG.SYSの段階で提示しなければならない ことになっていた。しかもこのキーナンバーには 限りがある（例えば20個）という仕組であった。

ユーザーの多い場合，これは非常に困ったこと である。それ以前に提供されたIBMのみに対応す るソフト（バージョン3.0）ではキーナンバーな しの形で“UNLIMITED WORKSTATION ACCESS "が可能であった。我々は丸善に善処方を 要請し, 丸善で調查の結果, ソフトウェアのバー ジョンアップと時期が重なったため, 混乱が生じ たことがわかった。即ち Meridian Data 社で

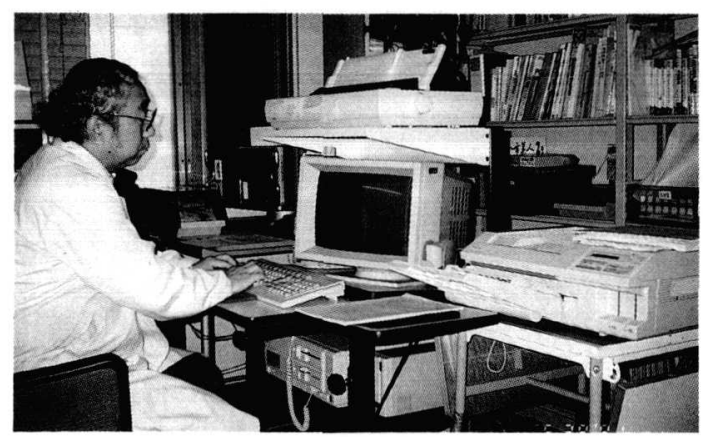

写真 1 .
は， $\mathrm{CD}$ サーバーのハードウェアとソフトウェア の両者を同時に購入する場合にはバージョン 3.0 のように制限無しのワークステーションからのア クセスが可能になっている筈なのであるが, ソフ トのみを購入する場合に提供するソフトを間違っ て納入してしまったというのであり, 問題は解決 した。

\section{LASSIEの成長亡発展}

平成 3 年 6 月現在, LASSIEの利用範囲は本学 の昭和キャンパスのみに限られており, データベー スむMEDLINEのみである。今年度の計画として, 我々は 3 キャンパスのLANを接続することによっ て, 学内のどこからであMEDLINEの検索を可能 にすることを考えている。桐生キャンパスの工学 部には生物工学科があるため, 生命科学に関する 文献の検索についての要望が特に強く, 荒牧キャ ンパスには教育学部, 教養部があって, やはり同 様の文献検索を必要としているからである。キャ ンパス間LANの接続に加えて, 更にCDサーバー を追加することによって, 現在荒牧にある図書館 本館でスタンドアロンで使用されているERIC, PsycLIT, 及び近々発売される医学中央雑誌を学 内からアクセスできるようにすることも今年度の 計画である。将来は工学関係のデータベースをも カバーしたいと思っている。本学のようにキャン パスの分散した大学ではキャンパスLAN とCDROMとのカップル即ちLASSIEは学内の情報資 源の共有に大きな役割を果たすべきものである。

稿を終るに当たり, 本学にLANの敷設を可能にし， 図書館情報の重要性を理解され, LASSIEの誕生に資金 を提供頂いた群馬大学前川 正学長に敬意を表し, 熱 く御礼を申し上げるとともに，LASSIEの誕生に熱心 に協力頂いた群馬大学附属図書館医学部分館の館員諸 氏に感謝する次第である。このシステムの構築には, 丸善, ユサコおよび東洋通信機の方々の緊密なるご協 力無しには成し遂げることは不可能であった。深く御 礼申し上げるとともにこの協力関係を他の大学, 機関 にも拡大されんことを願ってやまない。 